\title{
The Role of Mass Communication \& Globalization in Global Islamic PerspectiveFuturistic and Predictive Study of Modern Muslim World
}

\author{
Muhammad Umar Riaz Abbasi*1 ${ }^{1}$ Tariq Ejaz $^{2}$, Shamshad Akhtar ${ }^{3}$, Adul Rauf ${ }^{4}$ \\ ${ }^{1} \mathrm{PhD}$ Scholar National University of Modern Languages Islamabad Pakistan \\ Lecturer, Researcher, academic writer and Well-known Columnist, Author of three Books \\ Email: drumarabbasi101@gmail.com \\ ${ }^{2}$ Assistant Professor Air University Islamabad \\ ${ }^{3}$ Lecturer Punjab College Sialkot \\ ${ }^{4} \mathrm{PhD}$ Scholar Lecturer National University of Modern Languages Islamabad
}

\begin{abstract}
The analysis mainly deals with the processing of the qualitative data that is collected from the secondary method. The data analysis process involves collecting the qualitative data pertaining to the concept of globalization and mass communication. In accordance with the literature review, the data analysis would be analyzing the concept of globalization in light of Islam and its teachings. The data analysis would mainly be analyzing the literature obtained from the past research, news article and website. The data analysis would be mainly be looking for the concept of globalization and mass communication and its significance in light of the Islam perspective. ${ }^{1}$ Hence the analysis technique is content analysis. The article mainly focused on the contemporary academic and media approach toward different modules of mass communication. The integration of the philosophical legacy of antiquity in the Islamic world was a major enabling factor in the use of philosophical tradition among Muslim intellectuals. It gave rise to figures such as alFarabi, Ibn Sina (Avicenna), Ibn Rushd (Averroes), and others, who became well-known to mediaeval Europe as philosophers, commentators and exponents of the classical tradition going back to Plato and Aristotle. The public discourse of 'adab, grounded in philosophical and moral language and concerns, represents a significant part of the cosmopolitan heritage of ethics in Islam and reflects efforts to reconcile religiously and scripturally derived values with an intellectually and morally based ethical foundation. The Muslim philosophical tradition of ethics is therefore doubly significant: for its value in continuing and enhancing classical Greek philosophy and for its commitment to synthesizing Islam and philosophical thought.
\end{abstract}

Keywords: Globalization, Mass Communication, Muslim World, Islam, Future

Article Received: 10 August 2020, Revised: 25 October 2020, Accepted: 18 November 2020

${ }^{1}$ Kawulich, Barbara B. "Data analysis techniques in qualitative research." Journal of Research in Education 14, no. 1 (2004): 96-113. 


\section{Research methodology}

The data collection method refers to the strategy adopted for collecting the data. The data collection entails the secondary and primary method where, secondary sources refers to collecting the second hand and used information, and primary refers to collecting the first-hand information. The nature of these method varies the research instrument also varies at large, where for the secondary research method more emphasis is placed on gathering the existing data or information. This method mainly relies on the company websites, annual reports, news article, trade association and previous research studies. In comparison for the primary research methods, the aims are collecting the firsthand information therefore the research study commonly relies on conducting depth interviews, questionnaire, and focus group. This research, in particular, opts for the secondary methods where data is gathered from the previous research study, case study, and news article. The data would be pertaining to the concept of globalization and mass communication in accordance with the Islam perspective. ${ }^{2}$

\section{Introduction of Globalization}

The concept of globalization has become a universal phenomenon which facilitated technological advancement, the development of the cross-exchange cultural and exchange of the trade. Globalization is defined as a process by which the societies and communities across the globe exchange and integrate the culture, economic and political prospects. Previous research studies reveal that it is through globalization by which the world economy collectively has become globalized where interdependent

2 Johnston, Melissa P. "Secondary data analysis: A method of which the time has come." Qualitative and quantitative methods in libraries 3, no. 3 (2017): 619-626. production and consumption happens ${ }^{3}$. The emergence of the globalization happened in 1938 where the concept actually got recognition. Some of the positive side and aspect of the globalization are recognized as the facilitation of the foreign direct investment (FDI). Through globalization, developed and developing economics benefit out of each other's expertise and compete on the international and recognized level such as the foreign exchange market ${ }^{4}$. Some of the most interesting features are the shared consumption across the globe, most importantly the technology used in the production is internationally standardized, and the idea is a common property of the whole of humanity. ${ }^{5}$

Overview of Mass Communication and the modern Muslim world

Basically, mass communication comes under the umbrella of information and communication systems and it is defined as the communication of information from an individual, large or small group of people, or a small corporation to a large group of assorted and mysterious people ${ }^{6}$. Moreover, the most

${ }^{3}$ Ramsfield, T. D., B. J. Bentz, M. Faccoli, H. Jactel, and E. G. Brockerhoff. "Forest health in a changing world: effects of globalization and climate change on forest insect and pathogen impacts." Forestry 89, no. 3 (2016): 245-252.

4Ibrahim, AlhajiAhmadu. "The impact of globalization on Africa." International Journal of Humanities and Social Science 3, no. 15 (2013): 85-93.

${ }^{5}$ Burlacu, Sorin, CorneliuGutu, and Florin Octavian Matei. "Globalization-pros and cons." Calitatea 19, no. S1 (2018): 122-125. 6Dascălu, Dan Ioan. "Individualism and mass communication in the context of globalization." Procedia-Social and Behavioral Sciences 163 (2014): 1-6. 
commonly used channels for communication are the print media, radio, social media and television. From these channels currently, social media is a more influential channel of communicationrelated to mass communication ${ }^{7}$. In this contemporary world, technology plays a key role in the modernization of the media. Therefore, societies have normally required an efficient and effective means to spread and communicate the information. Hence, mass communication is comprehended to be an extension of this basic need. It can be defined as the public transfer of the information through the technology and media-driven channels to a huge number of beneficiaries $^{8}$. Through this people can easily recognize the numerous types of mass communication on which people depend on in their personal, professional and academic lives. These incorporate interactive media, print, visual, and majorly the other channels of social media ${ }^{9}$. A modern Muslim is normally a Muslim. Moreover, any Muslim is destined to obey the ways of their society in terms of the culture, food and clothing. On the other side, currently, a Muslim must go to an educational institute, learn about the secular studies, and normally deal with the society, which in turn to be better for every people ${ }^{10}$.

7Zheltukhina, M. R., N. I. Klushina, E. B. Ponomarenko, N. N. Vasilkova, and A. I. Dzyubenko. "Modern Media Influence: Mass Culture-Mass Consciousness-Mass Communication." XLinguae Journal 10, no. 4 (2017): 96-105.

${ }^{8}$ Hosseini, Mahtab. "Impact of Globalization on Translation and Cultural Acceptability of Audiovisual Texts."

9Wojdynski, Bartosz W., and Guy J. Golan. "Native advertising and the future of mass communication." (2016): 1403-1407.

${ }^{10}$ Dodd, Melissa. "Globalization, pluralization, and erosion: The impact of
A global perspective of Mass communication

The international perspective of the mass communication denotes to the entrance, receipt, dissemination and interchange of information and data on a global scale. Moreover, this majorly occurs through the internet along with the networks of different modern computers through which exchange of information $\operatorname{occurs}^{11}$.There is quite a difference in the conventional and modern media of communication, therefore, the mass media are seen currently as performing a major role in increasing globalization, expediting exchange of the culture together with the multiple flows of image and information amongst the countries via global news broadcasts, television programming, music, film and modern technologies ${ }^{12}$.

In the previous period of time, particularly prior to $1990 \mathrm{~s}$, mainstream systems of mass communication in developed nations of the globe were comparatively domestic in the scope, since the major communication media have become progressively global, encompassing their influence afar the nation-state to defeat and target the audiences globally. Moreover, the global flows of the information have largely been supported by the growth of the international capitalism, modern

shifting societal expectations for advocacy and public good." (2018).

11 Yan, Yan, and Kim Bissell. "The globalization of beauty: How is ideal beauty influenced by globally published fashion and beauty magazines?." Journal of Intercultural Communication Research 43, no. 3 (2014): 194-214.

${ }^{12}$ Kheeshadeh, Maryam. "Effects of globalization on tv and print media in Pakistan." International Journal of Asian Social Science 2, no. 9 (2012): 1441-1456. 
technologies and enhancing commercialization of international television, which has transpired as a result of the deregulation rules and policies implemented by the numerous countries in the US and Europe in direction to allow the explosion of satellite and cable channels ${ }^{13}$.

On the global level, mass communication performs a key role in developing the various communication channels and maintaining communication across the globe through their effective channels. This is because the development of the communication is a superior and strong area within the mass communication field and its emphasis on the usage of tools and techniques of mass communication for improvement of the socio-economic conditions in the emerging countries. In direction to comprehend the role of development of mass communication at the global level and the procedure of its development, it has been analyzed that there is a requirement of systematic comprehension of the development and communication of two procedures that are devoted by their nature when depicted in the association to their environment and others within the environment ${ }^{14}$.

Over the last 40 years, the initiation and beginning of the wireless communication and internet have transferred the procedure of communication in the society at the greater extend which is from the mass communication to the more interactive and interesting self-mass communication. In addition, this transformation and conversion in self-mass

${ }^{13}$ Matos, Calorina. "Globalization and the mass media." (2012).

14Sriramesh, Krishnamurthy, and

DejanVerčič. The global public relations handbook: Theory, research, and practice. Routledge, 2019. communication have participated conclusively to change the procedures related to social change. Power and strong associations have always relied on the control of information and communication that forage the neural networks which are constitutive of the human mind ${ }^{15}$.

Concept of Mass communication in Islam

The communication is the most significant element to humanity which cannot exist or survive without the vigorous channels of communication. Islam is the religion which is majorly based on the communication, and then in similarity to any religion, is confronting various challenges to progress and amend to innovativeness and is specific to the cultural and economic power and struggle of a dominant west ${ }^{16}$. On the other side, there is an increasing interest in Islam and the adherents' of Islam have been enhanced everywhere. On the other hand, there is a growing interest in Islam and the adherents' numbers have been increased everywhere ${ }^{17}$.

The most significant function of conveying cultural values and religious beliefs to the modern youth and young generation was executed by parents, the educational institutes, friends, elderly associates of the family before the

${ }^{15}$ Greenberg, Bradley S., and Michael B. Salwen. "Mass communication theory and research: Concepts and models." In An integrated approach to communication theory and research, pp. 75-88. Routledge, 2014.

16Kutor, SenanuKwasi. "Processes of Globalization and Its Effects on the Life of People in the Global South by Drawing Examples from Ghana." 17Khalil, Amal Ibrahim Abd El-Fattah. "The Islamic perspective of interpersonal communication." Journal of Islamic Studies 4, no. 2 (2016): 22-37. 
beginning of the technology ${ }^{18}$. In contrast, in this era of technology, philosophies of life together with the values of the culture and other significant measures and beliefs are created, conveyed, regulated to the modern generation via the media and mass communication. Similarly, in the process, the most used channels of mass communication are majorly used for transmitting the information ${ }^{19}$. Therefore, in this certain manner, the role of teachers, parents and scholars is significantly vanished by social media and mass communication.

The basic purpose that the world is rotating in which the individuals are belonging to the various religions, cultures and values and the countries confessing the same kind of ideologies of the life, and everyday life in general. The contemporary technology is used in normal routine in the educational institutes for providing more impactful teaching and sharing the Islamic values. Moreover, Information Technology (IT) and mass media make it quite easy for the individual to access the data and information related to any subject in the globe. For the communication of that particular data, still, the mass communication is used to communicate from one person to another and one person to many. In addition, there are various channels which offering the awareness of Islam such as news and Islamic channel

18Ugbam, Ogechukwu C., Benjamin Chukwu, and Ann Ogbo. "The effects of globalization on African culture: the Nigerian perspective." Journal of Business and Management 16, no. 4 (2014): 62-71. 19Khairunida, DaanDini, and Faisal Basri. "UTILIZATION OF MASS MEDIA FOR THE DEVELOPMENT OF ISLAMIC EDUCATION IN AL AMIN VOCATIONAL HIGH SCHOOL." UNIVERSITYCOMMUNITY ENGGAGEMENT October 8-10, 2018 3, no. 1 (2018): 171. websites and magazines are providing great services ${ }^{20}$.

Significance of Mass communication in Islam

Though the mass communication is considered to be a westernized invention, it has played an important role in transmitting the religion, belief, and values, essentially to the younger generation that is recognized as millennial. The most important and significant purpose of mass communication is recognized as helping to preach Islamic teaching and the Islamic doctrine of peace and love. Many of the researchers are of the opinion that the mass of communication serves the better purpose of facilitating the knowledge and its transmission. As addressing the fact that mass communication is modern technology, it mainly is significant in communicating Islam as the advance and modern technology that better helps in translating the Arabic language to the native language. This better helps in communicating and preaching the values and teaching of Islam.

It is also revealed that mass communication also helps in clarifying the image of Islam. It also lets the Islamic scholar communicate Islamic teaching though numerous channels, magazines and websites. Concentrating on the importance of mass communication simply helps in attracting and pursuing people to Islam. The better purpose modern technologies serve is it letting anyone access the information and better help in developing the education system. As revealing the role of mass communication and mass media, the common most example is the Peace TV that is playing an important role in clarifying the

20Sahikh, Zubair Ahmed, Sameera Sultan, Abdul GhafoorBaloach, and Irfan Khalid. "The role of mass media \& information technology in Islamic education." European Journal of Social Sciences 32, no. 3 (2012): 380-390. 
image of Islam and supports in educating about Islam. As considering the important phenomena of the globalization that is crosscultural integration, mass communication helps in translating the message of Islam and its teaching. Considering the scenario before the globalization, the Islamic literature was not easily available and only the interpretation by the local scholar was available but now books of different Islam scholar across the globe are easily accessible. The research reveals that the media is playing an integral and important role to spread Islam and educating the younger generations. ${ }^{21}$

The Role of Mass Communication \&
Globalization in Global Islamic Perspective

This study has a different background which is associated with mass communication and modern Islamic perspective. Therefore, the major focus of this research is related to the role of mass communication in the global Islamic perspective. The justification of this research is that in previous studies, there are not many studies which are defining the ideology of Islam and the role of Islamic education. Therefore, this research is to provide the solutions to aware the people about Islam with the positive impact of mass communication. In contrast, there is a negative influence of mass communication is also defined in the research. Moreover, self-mass communication plays an important role in the development of mass communication by adding various innovative and modern channels in mass

21Sahikh, Zubair Ahmed, Sameera Sultan, Abdul GhafoorBaloach, and Irfan Khalid. "The role of mass media \& information technology in Islamic education." European Journal of Social Sciences 32, no. 3 (2012): 380-390. communication. In addition, the more important element that has an impact on disclosure to the organization of family in which the crucial mass media messages are the education, kind of place of residence, the status of employment and participation of females in the development groups.

\section{Findings}

The mass communication along with the other media observed today are observed in significant growth in the globe. As currently, it is performing the important role in increasing the globalization, enabling the exchange of the culture together with the various flows of exchange in information and image amongst the countries across the global news broadcast, modern technologies and programming on televisions etc. ${ }^{22}$. There are various aspects through which people can exchange information related to Islam which is mainly through the effective mediums of social media. It helps to eradicate problems related to the awareness related to the ideology of Islam in the people ${ }^{23}$.

\section{Conclusion}

The other aspects are related to that by enabling the dynamic world space the globalization of media discourses are required. Therefore, the emerging communication media and mass communication have produced a different and innovative structure of the action and contemporary ways of social relations and

22Matos, Calorina. "Globalization and the mass media." (2012).

${ }^{23}$ Lazar, CâlinConstantin, and Sophie Deneuve. "Patients' perceptions of cosmetic surgery at a time of globalization, medical consumerism, and mass media culture: a French experience." Aesthetic surgery journal 33, no. 6 (2013): 878-885. 
interactions. It directs to the most difficult reordering of the patterns which are associated with the human interaction in the space. By adding the time with space then in the $20^{\text {th }}$ century, it results in enhance in the public space. Currently, the difference is that the globalization is different and it is treated as the globalization of the communications and media information companies ${ }^{24}$.

The reason of this is because this type of large firms are apprehensive with the significant development and growth, which means that they must create the associations with the other individuals and other powerful states in the globe. Hence, the decisive element that participated in the enlargement of globalization is unquestionably the media ${ }^{25}$. In contrast to this, recently media has taken a magnitude by taking support and making usage of channels of mass communication that has never met before. Similarly, the internet, access to the press in the information and remaining all individuals, by not considering what type of information they access and communicate. This sort of growth added an additional value to the development of mass communication in the globe ${ }^{26}$. The transition

${ }^{24}$ Esser, Frank, and JörgMatthes.

"Mediatization effects on political news, political actors, political decisions, and political audiences." In Democracy in the age of globalization and mediatization, pp. 177-201. Palgrave Macmillan, London, 2013.

25Munteanu, Nicoleta. "EFFECTS OF

GLOBALIZATION ON MASS

COMMUNICATION." RevistaAcademieiForte lorTerestre 16, no. 4 (2011).

26Kheeshadeh, Maryam. "Effects of Globalisation on Mass Media in the World." International Journal of Asian Social Science, 2 (10) (2007): 1672-1672. towards what Marshall Hodgson has termedthe 'Islamic ate' civilization marked two types of moral and intellectual beginnings. Both derived their inspiration from Islam's foundational texts and the unfolding of self-reflexive rational processes. The first involved, on the part of the early Muslims, a shift from a pre-Islamic Arab culture bound primarily by local, oral tradition, to one based on a revealed text, whose preservation and recording, in Arabic, created the conditions for the emergence of a new Islamic culture, based on the Qur'an and incorporating and extending the monotheistic imperative reflected in Judaism and Christianity. The second 'beginning' was influenced in part by the translation into Arabic and study of works of ancient philosophy, medicine and the sciences (to a lesser extent including those of ancient Iran and India). The moral discussions and intellectual forces that emerged from the juxtaposition and integration of these into fresh beginnings, facilitated to a certain extent by the presence of Jewish and Christian scholars, stimulated a concern for how moral and religious perspectives could be reconciled with intellectual modes of inquiry.

\section{Bibliography}

[1] Kawulich, Barbara B. "Data analysis techniques in qualitative research." 
Journal of Research in Education 14, no. 1 (2004): 96-113

[2] Johnston, Melissa P. "Secondary data analysis: A method of which the time has come." Qualitative and quantitative methods in libraries 3 , no. 3 (2017): 619-626.

[3] Ramsfield, T. D., B. J. Bentz, M. Faccoli, H. Jactel, and E. G. Brockerhoff. "Forest health in a changing world: effects of globalization and climate change on forest insect and pathogen impacts." Forestry 89, no. 3 (2016): 245-252.

[4] Ibrahim, AlhajiAhmadu. "The impact of globalization on Africa." International Journal of Humanities and Social Science 3, no. 15 (2013): 85-93.

[5] Burlacu, Sorin, CorneliuGutu, and Florin Octavian Matei. "Globalization-pros and cons." Calitatea 19, no. S1 (2018): 122-125.

[6] Dascălu, Dan Ioan. "Individualism and mass communication in the context of globalization." ProcediaSocial and Behavioral Sciences 163 (2014): 1-6.

[7] Zheltukhina, M. R., N. I. Klushina, E. B. Ponomarenko, N. N. Vasilkova, and A. I. Dzyubenko. "Modern Media Influence: Mass Culture-Mass Consciousness-Mass Communication." XLinguae

Journal 10, no. 4 (2017): 96-105.

[8] Hosseini, Mahtab. "Impact of Globalization on Translation and Cultural Acceptability of Audiovisual Texts."

[9] Wojdynski, Bartosz W., and Guy J. Golan. "Native advertising and the future of mass communication." (2016): 1403-1407.
[10] Dodd, Melissa. "Globalization, pluralization, and erosion: The impact of shifting societal expectations for advocacy and public good." (2018).

[11] Yan, Yan, and Kim Bissell. "The globalization of beauty: How is ideal beauty influenced by globally published fashion and beauty magazines?." Journal of Intercultural Communication Research 43, no. 3 (2014): 194-214.

[12] Kheeshadeh, Maryam. "Effects of globalization on tv and print media in Pakistan." International Journal of Asian Social Science 2, no. 9 (2012): 1441-1456.

[13] Matos, Calorina. "Globalization and the mass media." (2012).

[14] Sriramesh, Krishnamurthy, and DejanVerčič. The global public relations handbook: Theory, research, and practice. Routledge, 2019.

[15] Greenberg, Bradley S., and Michael B. Salwen. "Mass communication theory and research: Concepts and models." In An integrated approach to communication theory and research, pp. 75-88. Routledge, 2014.

[16] Matos, Calorina. "Globalization and the mass media." (2012).

[17] Lazar, CâlinConstantin, and Sophie Deneuve. "Patients' perceptions of cosmetic surgery at a time of globalization, medical consumerism, and mass media culture: a French experience." Aesthetic surgery journal 33, no. 6 (2013): 878-885.

[18] Esser, Frank, and JörgMatthes. "Mediatization effects on political news, political actors, political 
decisions, and political audiences."

In Democracy in the age of globalization and mediatization, pp. 177-201. Palgrave Macmillan, London, 2013.

[19] Munteanu, Nicoleta. "EFFECTS OF GLOBALIZATION ON MASS COMMUNICATION." RevistaAcad emieiFortelorTerestre 16, no. 4 (2011).

[20] Kheeshadeh, Maryam. "Effects of Globalisation on Mass Media in the World." International Journal of Asian Social Science, 2 (10) (2007): 1672-1672.

[21] Kutor, SenanuKwasi. "Processes of Globalization and Its Effects on the Life of People in the Global South by Drawing Examples from Ghana."

[22] Khalil, Amal Ibrahim Abd El-Fattah. "The Islamic perspective of interpersonal communication." Journal of Islamic Studies 4, no. 2 (2016): 22-37. 